\title{
Effect of Coffee-like Green Tea Preparation on Cytotoxicity of Human Cancer and Normal Cells
}

\author{
Yean Guy Moon', Jung Min Kwon', Jong Cheol Kim², Han Min Park', Yong Un Cho', Kwan Ju Jung ${ }^{5}$ \\ and Yeong Lea $\mathrm{Ha}^{1}$ * \\ ${ }^{1}$ Division of Applied Life Science (BK21 Program), Graduate School, and Institute of Agriculture \& Life Science, Gyeongsang National \\ University, Jinju 660-701, Korea \\ ${ }^{2}$ Institute of Hadong Green Tea, Hadong 667-822, Korea \\ ${ }^{3}$ Department of Environmental Materials Science, Gyeongsang National University, Jinju 660-701, Korea \\ ${ }^{4}$ Department of Pharmaceutical Engineering, Gyeongnam National University of Science and Technology, Jinju 660-758, Korea \\ ${ }^{5}$ Bio21 center, Jinju 660-778, Korea
}

Received October 7, 2012 /Revised December 19, 2012 /Accepted January 10, 2013

\begin{abstract}
The cytotoxicity of coffee-like green tea (CLGT) was determined in a human breast cancer cell line, MCF-7; a human prostate cancer cell clone, PC-3; a human neuroblastoma cell line, SK-N-SH; and a rat cardiomyoblast cell line, $\mathrm{H} 9 \mathrm{c} 2$, with reference to green tea leaves (GTL). The CLGT was prepared by roasting the GTL for $60 \mathrm{~min}$ at $240^{\circ} \mathrm{C}$ in a temperature-controlled frying pan. The CLGT preparation imitated the flavor and taste characteristics of coffee fairly well according to sensory analysis. The CLGT preparation had no adverse cytotoxic effects on the cancer cells or the normal cells compared to GTL. No significant change in the antioxidant activity was seen in the CLGT preparation compared to that of GTL. The amount of total protein, sugar, and phenolic compounds was reduced in the preparation relative to those in GTL, a fact that might explain the coffee-like flavor and/or taste characteristics of the CLGT preparation. These results suggest that CLGT prepared by roasting GTL for $60 \mathrm{~min}$ at $240^{\circ} \mathrm{C}$ does not show any adverse effects on cancer cells and normal cells compared to GTL. They imply that CLGT could be safe for human consumption.
\end{abstract}

Key words : Green tea leaves (GTL), roasted green tea leaves (RGT), coffee-like green tea (CLGT), cytotoxicity, human cancer cells

\section{서 론}

녹차(green tea leaves: GTL)는 차나무(Camellia sinensis)엽 을 다양한 방법으로 가공한 식품으로 녹차 특유의 향미[향 (flavor)과 맛(taste)]를 갖는 기호성 식품이다. 또한 GTL은 암을 비롯한 각종 만성질병의 예방-치료와 훙분, 강심, 이뇨 등의 약리작용과 신체조절 기능을 갖는 기능성 식품이다 $[1$, $6,10,25]$.

GTL은 기호성, 약리작용 및 생리활성을 갖기 때문에 생산 량과 소비가 증가 되었지만, 2005년을 기점으로 소비자의 소 비패턴 변화추세로 GTL의 소비가 감소하고 있다[29]. GTL은 건강을 중요시하는 중 노년층 소비자에 의해 주로 소비되고 있고, 청소년층 소비자는 GTL의 풋내 또는 특유한 향미 때문

\footnotetext{
*Corresponding author

Tel : +82-55-772-1964, Fax : +82-55-772-1969

E-mail : ylha@gnu.ac.kr

This is an Open-Access article distributed under the terms of the Creative Commons Attribution Non-Commercial License (http://creativecommons.org/licenses/by-nc/3.0) which permits unrestricted non-commercial use, distribution, and reproduction in any medium, provided the original work is properly cited.
}

에 소비를 기피하는 경향이 있다. 이들 청소년층 소비자 대부 분은 자극성이 강하고, 향미가 강한 커피나 콜라와 같은 서구 식 기호식품에 노출되어 이들을 즐겨 소비하고 있다. 따라서 청소년층 젊은이들의 GTL 소비를 증가시키기 위해서는 GTL 에 커피와 유사한 강한 향미를 부여 한 커피유사 녹차 (coffee-like green tea: CLGT)를 제조하는 것이 필요하다. CLGT는 커피 가공과 같이 GTL을 고온에서 roasting 함으로 써 제조할 수 있을 것이다.

Roasting은 식품에 고유한 향미와 색깔을 부여하기 위한 수단으로 널리 사용되고 있다. Roasting은 식품성분을 분해, 합성, 축합 등의 화학반응을 통해 유용성분으로 전환시키기 때문에 커피, 오가피, 율무, 둘굴레 등에 고유한 향미성분을 부여하기 위해 많이 활용되고 있다[16, 24]. 그러나 식품의 roasting은 돌연변이성 물질 및 발암성 물질을 생생하기도 한 다 $[2,9,12,19,20]$. 따라서, CLGT를 제조하기 위하여 GTL을 roasting할 경우, 인체에 유해한 돌연변이성 및 발암물질 생성 을 초래 할 수도 있을 것이다. 본 연구에서는 GTL을 고온에서 roasting하여 CLGT를 제조하고, 이 CLGT의 독성을 인체 암 세포와 인체 정상세포를 대상으로 검증하였다. 


\section{재료 및 방법}

\section{재료}

GTL (우전엽)은 하동녹차연구소(하동, 경남)에서 제공받았 고 인체 유방암세포 주MCF-7, 인체 전립선암세포 주PC-3, 인 체 신경모세포 주SK-N-SH 및 쥐 심근세포 주H9c2는 Korea Cell Line Bank (Seoul, Korea)에서 구입하였다. Dulbecco' Modified Eagle Medium/Ham' F-12 nutrient (DMEM/F12), Roswell Park Memorial Institute (RPMI) 1640, fetal bovine serum (FBS), penicillin $(10,000 \mathrm{U} / \mathrm{ml})$ 과 streptomycin $(10$ $\mathrm{mg} / \mathrm{ml}$ ), 0.25\% trypsin-EDTA는 Gibco BR사 (Rockville, MD), phosphate buffered saline (PBS), 3-(4,5-dimethylthiazol2yl)-2,5-diphyenyltetra-zolium (MTT) 및 bovine serum albu$\min$ (BSA)은 Amresco사(Solon, $\mathrm{OH}$ )에서 구입하였다. Dimethyl sulfoxide (DMSO), polyvinyl difluoride (PVDF) membrane, a-a-diphenyl- $\beta$-picrylhydrazyl (DPPH), Folin -Ciocalteu's phenol 시약, gallic acid 및 Bradford 시약은 Sigma-Aldrich사(St. Louis, MO)에서 구입하였다. Radio immune precipitation assay (RIPA) buffer는 Cell Signaling Technology사(Danvers, CO)에서 ECL detection reagent는 Amersham사(Berkshire, UK)에서 구입하였다. B-Actin, caspase-3 goat anti-rabbit IgG-HRP는 Santa Cruz Biotechnology 사(Santa Cruz, CA), caspase-3 rabbit polyclonal antibody는 Delta Biolabs사(Campbell, CA), mouse monoclonal anti- $\beta$ -actin은 Sigma-Aldrich사에서 구입하였다. Nunc cell culture plate (24와 96well-plate)와 dish (100 mm dish)는 SigmaAldrich사로부터 구입하였다. 그 외 사용된 시약은 reagent grade 이상이었다.

\section{GTL의 roasting 및 시료조제}

GTL $(500 \mathrm{~g})$ 을 온도 $\left(200^{\circ} \mathrm{C}, 240^{\circ} \mathrm{C}\right)$ 가 조절되는 fry-pan에서 $10,30,60$ 및 120분 roasting 하였다. GTL 및 roasting한 녹차엽 (RGT) $1 \mathrm{~g}$ 을 $80^{\circ} \mathrm{C}$ 찻물 $(100 \mathrm{ml})$ 에 3 분간 침출하여 관능검사에 사용하다. 이를 농축 $(100 \mathrm{mg} / \mathrm{ml})$ 하고 membrane $(0.2 \mu \mathrm{m})$ 여 과하여 세포독성, caspase-3 발현 및 항산화능 검증시료와 일 반화학성분 분석시료로 사용하였다.

분쇄한 시료 $(0.3 \mathrm{~g})$ 를 증류수 $(30 \mathrm{ml})$ 와 혼합하여 $80^{\circ} \mathrm{C}$ 에서 1시간 추출하였다. 추출액을 Whatman 여과지(No. 4)로 여과 하여 여액을 ethyl acetate $(50 \mathrm{ml})$ 로 5 분 추출하였다. 추출 상 층액을 회수하여 감압농축 하였다. 농축물을 다시 methanol $(5 \mathrm{ml})$ 에 용해한 다음 membrane 필터 $(0.2 \mu \mathrm{m})$ 로 여과하여 catechin계 화합물 분석시료로 사용하였다.

\section{관능평가}

시료 열수추출물의 향미를 관능검사로 평가하였다. 관능평 가 요원은 충분한 훈련을 거쳐 품질 차이를 식별 할 수 있는
능력을 갖춘 20 대 대학생 $(15$ 명)으로 구성하였다. 미지근한 물 로 입안을 헹군 후 시료의 향미를 평가하였다. 평가요원은 평 가를 모두 마칠 때까지 정숙히 자리를 지켰다. 평가 항목은 5점법으로 녹차 맛 및 향 1점, 녹차와 유사한 맛 및 향 2점, 녹차와 커피의 중간인 맛 및 향 3 점, 커피에 가까운 맛 및 향 4점, 커피 맛 및 향 5점으로 평가 하였다.

세포독성 및 caspase-3 발현 측정

\section{세포배양}

MCF-7 세포와 SK-N-SH 세포는 10\% FBS와 penicillin/ streptomycin이 함유된 DMEM/F-12 배지에서, PC-3와 H9c2 세포는 $10 \% \mathrm{FBS}$ 와 penicillin/streptomycin이 함유된 RPMI 1640 배지에서 $5 \% \mathrm{CO}_{2}$ 가 공급되는 배양기 $\left(37^{\circ} \mathrm{C}\right)$ 에서 배양하 였다[22]. 세포가 $80 \%$ 정도 자라면 배지를 제거한 후 PBS 세척 (3회), $0.25 \%$ trypsin-EDTA 용액 처리( $1 \mathrm{ml}, 5$ 분), 원심분리 $(1,500 \mathrm{rpm}, 15$ 분 $)$ 하여 분리한 세포를 세포독성과 caspase-3 발현에 사용하였다.

\section{세포독성 검증}

시료의 세포독성은 Rakib 등[22]의 방법에 준하여 MTT assay로 측정하였다. 세포를 24-well plate $\left(1 \times 10^{5}\right.$ cells/0.5 $\mathrm{ml} / \mathrm{well}$ )에서 24시간 배양하였다. 이들로부터 배지를 제거하 고 PBS로 세척(3회) 후 serum free media (SFM)를 넣고 시료 를 농도 별 $(0,50,250,500 \mathrm{\mu g} / \mathrm{ml})$ 로 처리하여 48 시간 배양하 였다. 다시 세포의 배지를 제거하고, $\mathrm{PBS}$ 로 세척(3회)하고, MTT 시약 $(5 \mathrm{mg} / \mathrm{ml} \mathrm{PBS})$ 을 well당 $100 \mu \mathrm{ll}$ 가하고 $37^{\circ} \mathrm{C}$ 에서 3시간 배양하였다. 그 후 MTT 용액을 제거, PBS 세척(3회), DMSO 처리(well당 $200 \mu \mathrm{ll}$ )하여 formazan crystal을 녹였다. 이를 새로운 96-well plate의 well당 $100 \mu \mathrm{l}$ 옮겨 Anthos 2020 model microplate reader (Anthos Labtech Instruments, Wals, Austria)로 $570 \mathrm{~nm}$ 에서 흡광도를 측정하여 세포의 생육 정도를 계산하였다.

\section{Caspase- 3 의 발현}

Caspase-3의 발현은 Western blotting으로 Rakib 등[22]의 방법에 준하여 분석하였다. 세포를 culture dish $(100 \mathrm{~mm})$ 에 seeding $\left(3 \times 10^{6}\right.$ cells)한 후 24 시간 배양하였다. 배지제거, PBS 세척(3회), serum free media (SFM) 첨가, 시료 농도 별(0, 50, $250,500 \mu \mathrm{g} / \mathrm{ml}$ 로 처리하고 48시간 배양하였다. $0.25 \%$ tryp$\sin -\mathrm{EDTA}(1 \mathrm{ml})$ 를 처리하고, 회수하여 PBS로 세척(3회)하였 다. 이 세포의 protein을 lyses buffer인 RIPA로 추출하고 Bradford 시약으로 함량을 측정하였다. Protein을 $7.5 \%$ SDS-PAGE를 이용하여 분리하고, PVDF membrane에 옮겨 caspase-3 protein을 primary antibody와 secondary antibody 를 처리하고 ECL detection reagent로 감광하여 caspse-3를 측정하였다. 


\section{항산화능 측정}

시료의 항산화성은 DPPH 라디칼 소거능으로 측정하였다 [4]. DPPH 용액 $(0.3 \mathrm{mM} \mathrm{DPPH} / \mathrm{ml}$ methanol)에 시료를 농도 별 $(0.5,1,2,3 \mathrm{mg})$ 로 첨가하고 methanol로 $3 \mathrm{ml}$ 로 보정하였다. Vitamin C의 DPPH 소거능도 시료처리와 같이 vitamin C를 농도 별 $(0.5,1,2,3 \mu \mathrm{g})$ 로 첨가하여 측정하였다. 처리시료의 흡광도 $(\lambda \max 517 \mathrm{~nm})$ 를 Beckman DU-8 spectrophotometer (Brea, $\mathrm{CA}$ )로 측정하여 시료의 $\mathrm{SC}_{50}$ (scavenging activity)를 계산하였다. $\mathrm{SC}_{50}$ 은 $\mathrm{DPPH}$ 용액에 시료 첨가 1 분 후의 $\mathrm{DPPH}$ 의 농도(흡광도)가 $50 \%$ 감소하는데 필요한 시료의 농도로 계 산하였다.

\section{화학성분 분석}

\section{Catechin계 화합물 및 카페인 함량}

Catechin계 화합물은 El-Shahawi 등의 방법[8]에 준하여 Dionex Ultimate-3000 HPLC (Sunnyvale, CA)를 이용하여 분 석하였다. Column은 TSK-gel C18 column $(4.6 \times 250 \mathrm{~mm}$; Waters, Milford, MA)을 사용하였고, mobile phase는 $0.2 \%$ $\mathrm{H}_{3} \mathrm{PO}_{4} /$ wateracetonitrile $(8.5: 1.5, \mathrm{v} / \mathrm{v})$ 을 사용하였다. Flow rate는 $1 \mathrm{ml} / \mathrm{min}$ 였고 peak는 $254 \mathrm{~nm}$ 에서 측정하였다.

\section{Total phenol 함량}

Total phenol 함량은 Singleton과 Rossi Jr.의 방법[26]에 준 하여 측정하였다. 시료 $(200 \mu \mathrm{l})$ 에 증류수 $2.6 \mathrm{ml}$ 와 FolinCiocalteu's phenol 시약 $(200 \mu \mathrm{ll})$ 을 첨가하여 vortex 후 6분간 상온에서 반응시켰다. $7 \% \mathrm{Na}_{2} \mathrm{CO}_{3}$ 용액 $2 \mathrm{ml}$ 를 첨가하여 90 분 동안 정치시킨 후 Beckman DU-8으로 $750 \mathrm{~nm}$ 에서 흡광도를 측정하였다. Gallic acid를 표준물질로 사용하여 total phenol 함량은 건물에 대한 gallic acid equivalent mg (mg GAE/g dry weight)으로 표시하였다.

\section{Total sugar 함량}

Total sugar 함량은 phenol-sulfuric acid법[7]으로 측정하였 다. Test tube에 시료 $250 \mu \mathrm{ll}, 5 \%$ phenol 용액 $150 \mu \mathrm{ll}$, 95\% sulfuric acid $750 \mu 1$ 를 첨가한 후 vortex하고 $95^{\circ} \mathrm{C}$ 항온수조에서 5 분간 반응하고 실온에서 5 분간 방치 하였다. 반응 시료의 흡 광도를 Beckman DU-8 Spectrometer를 이용하여 $490 \mathrm{~nm}$ 에서 측정하였다. Total sugar 함량은 glucose $(\%)$ 로 표시하였다.

\section{Total protein 함량}

Total protein 함량은 Bradford시약을 이용하여 정량 하였 다. Test tube에 시료 $10 \mu \mathrm{l}$, 증류수 $90 \mu \mathrm{l}$, Bradford 시약 900 $\mathrm{ll}$ 를 첨가하여 voltex 후 Beckman DU-8 Spectrometer로 595 $\mathrm{nm}$ 에서 흡광도를 측정하였다. BSA를 표준물질로 사용하여 total protein의 함량은 건물 중에 대한 \%로 표시하였다.

\section{$\mathrm{CLGT}$ 의 휘발성 향기성분 분석}

휘발성분의 분석은 Lee 등의 방법[17]에 준하여 증류한 n-pentane/diethyl ether 혼합용매(1:1, v/v) $100 \mathrm{ml}$ 를 사용하 여 상압에서 3시간 동안 simultaneous distillation extraction (SDE)장치로 추출하였다. 용매의 수분을 제거하고 약 $0.5 \mathrm{ml}$ 로 농축하여 GC/MS는 HP6890 Series gas chromatograph$\mathrm{MS}$ 로 분석하였다. Injector와 ion source의 온도는 각각 $250^{\circ} \mathrm{C}$ 와 $230^{\circ} \mathrm{C}$ 이며, column은 DB-Wax $(60 \mathrm{~m} \times 0.25 \mathrm{~mm}$, i.d., 0.25 um film thickness, J\&W, USA)를 사용하였다. Oven temperature는 $40^{\circ} \mathrm{C}$ 에서 3 분간 유지한 다음 $2^{\circ} \mathrm{C} / \mathrm{min}$ 의 속도로 $120^{\circ} \mathrm{C}$ 까지 상승 시켜 5 분간 유지하고 동일한 속도로 $180^{\circ} \mathrm{C}$ 까지 상 승시켜 5 분간 유지하였으며, 다시 $4^{\circ} \mathrm{C} / \mathrm{min}$ 의 속도로 $200^{\circ} \mathrm{C}$ 까 지 상승시킨 후 10 분간 유지한 다음 $5^{\circ} \mathrm{C} / \mathrm{min}$ 의 속도로 $230^{\circ} \mathrm{C}$ 까지 상승시킨 후 10 분간 유지하도록 설정하였다. Carrier gas 는 nitrogen을 사용하였고, flow rate는 $1.0 \mathrm{ml} / \mathrm{min}$ 였다.

\section{통계분석}

Data는 mean $\pm \mathrm{SD}$ 로 나타내었다. 통계분석은 SPSS 통계 프 로그램 14.0 version (SPSS Inc, Chicago, IL)을 이용하여 분석 하였다. Data의 유의성 검증은 Duncan의 multiple range test 또는 t-test로 검증하였다.

\section{결 과}

\section{$\mathrm{RGT}$ 의 관능평가}

$\mathrm{GTL}$ 과 $\mathrm{RGT}$ 시료를 $80^{\circ} \mathrm{C}$ 물로 추출한 침출액에 대한 관능검 사는 15 명의 관능평가 요원을 구성하여 평가하였다(Tables 1, 2). Roasting 효과를 측정하기 위해 여러 조건에서 roasting한 RGT 물 추출물에 대해 향미를 5점 법으로 평가하였다. 먼저 향은 녹차향 1점, 녹차향에 가까움 2점, 녹차향과 커피향이 비슷하게 남 3 점, 커피향에 가까움 4 점, 커피향 5 점을 부여하 여 평가하였고(Table 1), 맛도 향과 같은 방법으로 평가하였다 (Table 2). GTL을 $240^{\circ} \mathrm{C}$ 에서 60 분간 roasting한 RGT에서 커피 와 가장 유사한 향미를 나타내어 $240^{\circ} \mathrm{C}$ 에서 60 분간 roasting한 RGT 시료를 CLGT로하여, 여러 가지 실험에 사용하였다.

\section{CLGT의 인체 암세포 및 정상세포 독성}

GTL과 CLGT의 물 추출물이 인체암세포인 MCF-7 (Fig. 1A)과 PC-3 (Fig. 1B)의 증식에 미치는 영향을 조사하였다. 이 들 세포에 GTL과 CLGT 시료를 농도 별로 처리하고 48 시간 후 생존 세포를 측정한 결과, 두 시료 모두 농도가 증가할수록 세포 수는 현저히 감소하였고, GTL과 CLGT 시료는 MCF-7 세포와 PC-3 세포 성장에 농도 의존적으로 세포증식 억제효과 가 있음을 알 수 있었다. 그러나 두 시료 GTL과 CLGT간의 세포 증식억제 효과에는 유의적인 차이가 없어 roasting에 의 한 세포독성은 없었다.

인체 정상세포인 SK-N-SH (Fig. 2A)와 쥐 심근세포인 H9c2 (Fig. 2B) 증식에 대해 GTL과 CLGT 시료를 농도 별로 처리한 
Table 1. Flavor evaluation of CLGT preparation derived by roasting GTL

\begin{tabular}{|c|c|c|c|c|c|c|c|}
\hline \multirow{2}{*}{\multicolumn{2}{|c|}{ Treatment ${ }^{1)}$}} & \multicolumn{5}{|c|}{ Flavor description ${ }^{2)}$} & \multirow{2}{*}{$\begin{array}{l}\text { Average } \\
\text { score }\end{array}$} \\
\hline & & $\begin{array}{l}\text { Green tea } \\
\text { (1 point })\end{array}$ & $\begin{array}{l}\text { Slight green tea-like } \\
\text { ( } 2 \text { points })\end{array}$ & $\begin{array}{l}\text { Intermediate } \\
(3 \text { points })\end{array}$ & $\begin{array}{l}\text { Slight coffee-like } \\
\text { (4 points) }\end{array}$ & $\begin{array}{l}\text { Coffee-like } \\
\text { (5 points) }\end{array}$ & \\
\hline & trol & 15 & & & & & 1.00 \\
\hline \multirow{4}{*}{$200^{\circ} \mathrm{C}$} & $10 \mathrm{~min}$ & 5 & 10 & & & & 1.67 \\
\hline & $30 \mathrm{~min}$ & 5 & 10 & & & & 1.67 \\
\hline & $60 \mathrm{~min}$ & 2 & & 6 & 7 & & 3.20 \\
\hline & $120 \mathrm{~min}$ & 2 & & 3 & 3 & 7 & 3.87 \\
\hline \multirow{4}{*}{$240^{\circ} \mathrm{C}$} & $10 \mathrm{~min}$ & 3 & 3 & & 9 & & 3.00 \\
\hline & $30 \mathrm{~min}$ & 2 & 2 & 2 & 7 & 2 & 3.33 \\
\hline & $60 \mathrm{~min}$ & & 2 & 4 & 3 & 6 & 3.87 \\
\hline & $120 \mathrm{~min}$ & & 3 & 3 & 3 & 6 & 3.80 \\
\hline
\end{tabular}

${ }^{1)}$ GTL was roasted in a temperature-controlled fry-pan.

${ }^{2)}$ Flavor description was evaluated by a well-trained 15 college students.

Table 2. Taste evaluation of CLGT preparation derived by roasting GTL

\begin{tabular}{|c|c|c|c|c|c|c|c|}
\hline \multirow{2}{*}{\multicolumn{2}{|c|}{ Treatment ${ }^{1)}$}} & \multicolumn{5}{|c|}{ Taste description $^{2}$} & \multirow[b]{2}{*}{$\begin{array}{c}\text { Average } \\
\text { score }\end{array}$} \\
\hline & & $\begin{array}{l}\text { Green tea } \\
\text { (1 point) }\end{array}$ & $\begin{array}{l}\text { Slight green tea-like } \\
\text { (2 points) }\end{array}$ & $\begin{array}{l}\text { Intermediate } \\
\text { (3 points) }\end{array}$ & $\begin{array}{l}\text { Slight coffee-like } \\
\text { (4 points) }\end{array}$ & $\begin{array}{l}\text { Coffee-like } \\
(5 \text { points })\end{array}$ & \\
\hline & ontrol & 15 & & & & & 1.00 \\
\hline \multirow{4}{*}{$200^{\circ} \mathrm{C}$} & $10 \mathrm{~min}$ & 8 & 7 & & & & 1.47 \\
\hline & $30 \mathrm{~min}$ & 3 & 6 & 4 & 2 & & 2.33 \\
\hline & $60 \mathrm{~min}$ & & & 4 & 11 & & 3.73 \\
\hline & $120 \mathrm{~min}$ & & 2 & 6 & 7 & & 3.33 \\
\hline \multirow{4}{*}{$240^{\circ} \mathrm{C}$} & $10 \mathrm{~min}$ & 3 & 8 & & 4 & 1 & 2.67 \\
\hline & $30 \mathrm{~min}$ & & 5 & & 10 & & 3.33 \\
\hline & $60 \mathrm{~min}$ & & & & 10 & 5 & 4.33 \\
\hline & $120 \mathrm{~min}$ & & 1 & & 8 & 6 & 4.27 \\
\hline
\end{tabular}

${ }^{1)}$ GTL was roasted in a temperature-controlled fry-pan.

${ }^{2)}$ Taste description was evaluated by a well-trained 15 college students.

결과 GTL과 CLGT 시료 최대 처리량인 $500 \mu \mathrm{g} / \mathrm{ml}$ 농도까지 증식 저해효과는 나타나지 않았다. 또한 이들 두 시료의 SK-N-SH 세포와 H9c2 세포 증식에 대한 효과는 유의적인 차 이가 없어 roasting 효과는 없었다.

Caspase-3는 세포의 mitochondrial dysfunction에 따른 apoptosis 유도에 executive 역할을 하는 효소로 핵과 mitochondria의 외 막에 불활성 상태로 존재하다가 유도 자극에 의하여 활성화 되어 apoptosis를 유도한다. 따라서 GTL과 RGT 시료 모두가 인체암세포인 MCF-7과 PC-3에 대해 apoptosis를 유도하는지를 조사하기 위해 cytosol의 caspase-3 효 소 protein 농도를 측정하였다. MCF-7 세포(Fig. 3)와 PC-3 세 포(Fig. 4)에서 GTL과 CLGT 시료 처리에 따른 농도 의존적으 로 caspase-3 protein 함량이 증가하였고, 두 시료의 효과 차 이는 없었다. 이 결과는 GTL과 CLGT 시료가 MCF-7 세포와 PC-3 세포에 대한 독성효과는 apoptosis를 유도하였음을 의
미한다.

\section{CLGT의 항산화능 및 catechin 함량}

Table 3에는 GTL과 CLGT 시료의 항산화능을 vitamin C로 환산(vitamin $\mathrm{C} \mathrm{mg} / \mathrm{g}$ )하여 $\mathrm{DPPH}$ radical 소거능 $\left(\mathrm{SC}_{50}\right)$ 을 나 타내었다. GTL과 CLGT 시료의 $\mathrm{SC}_{50}$ 값은 각각 $14.1 \mathrm{mg}$ vita$\min \mathrm{C} / \mathrm{g}$ 과 $11.6 \mathrm{mg}$ vitamin $\mathrm{C} / \mathrm{g}$ 로 $\mathrm{GTL}$ 시료가 다소 높은 항산화활성을 나타내었지만 유의차는 없었다. 또한 GTL과 CLGT 시료의 total phenol 함량은 각각 $90.9 \mathrm{mg}$ 과 $86.2 \mathrm{mg}$ $\mathrm{GAE} / \mathrm{g}$ 로 유의적인 차이는 없었다. GTL과CLGT 시료의 total sugar의 함량(glucose \%)은 각각 $6.5 \%$ 와 $5.6 \%$ 로 roasting에 의해 감소되었지만 유의차는 없었고, total protein 함량은 각 각 $4.9 \%$ 와 $2.8 \%$ 로 CLGT 시료에서 유의적으로 낮았다 $(p<0.05)$.

Fig. 5는 GTL과 CLGT 시료의 catechin계 화합물의 HPLC 
(A)

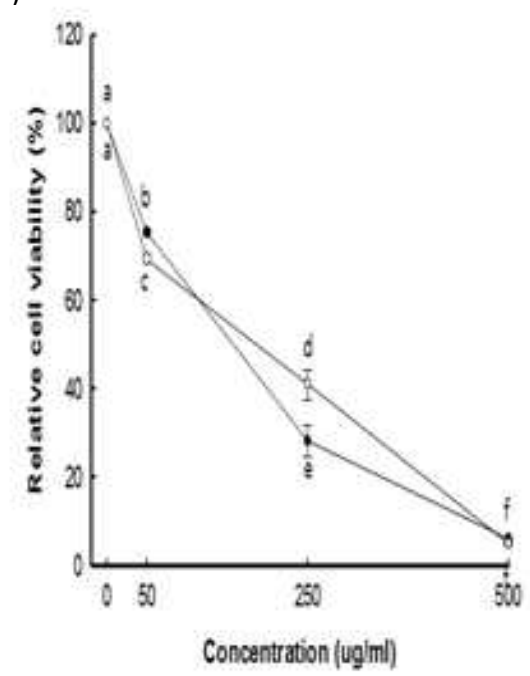

(B)

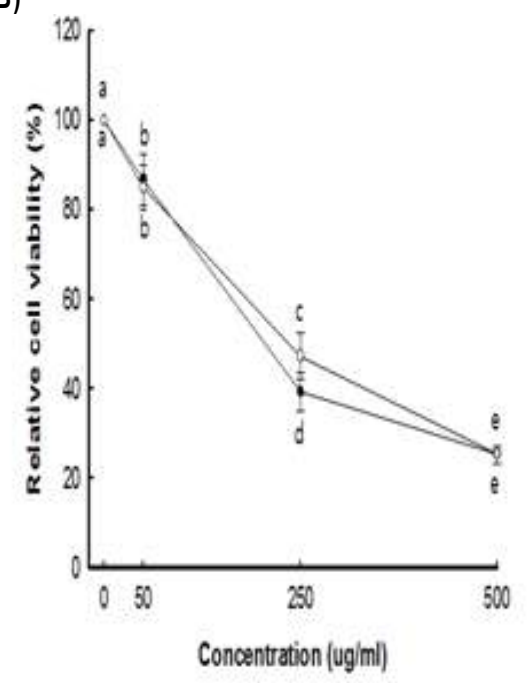

Fig. 1. Effects of GTL and CLGT preparation on the growth of human breast cancer MCF-7 (A) and human prostate cancer PC-3 cells (B) grown for 2 days. Line identification: closed circle, GTL; and open circle, CLGT. Values are means \pm SD $(n=3)$. Means not sharing same superscript letters are different at $p<0.05$ by $\mathrm{t}$-test.

(A)

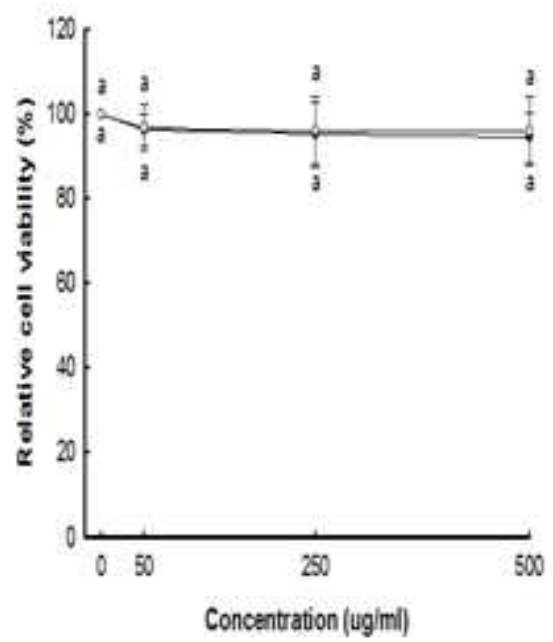

(B)

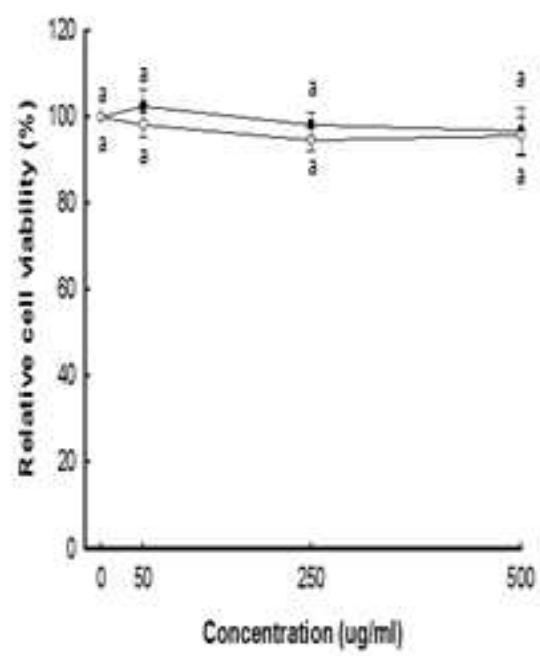

Fig. 2. Effects of GTL and CLGT preparation on the growth of human neuroblastoma SK-N-SH cells (A) and rat cardiomyoblast H9c2 cells (B) grown for 2 days. Line identification: closed circle, GTL; and open circle, CLGT. Values are means \pm SD ( $n=3$ ). Means not sharing same superscript letters are different at $p<0.05$ by t-test.

chromatogram이고, 그 함량을 Table 4에 나타내었다. GTL과 CLGT 시료에는 gallocatechin (GC), epigallocatechin (EGC), catechin, caffeine, epicatechin (EC), epigallocatechin gallate (EGCG), gallocatechin gallate (GCG), epicatechin gallate (ECG)등의 화합물이 검출되었다. 이들 성분 중 $\mathrm{GTL}$ 시료에 비해 CLGT 시료에서 EGC, catechin, EC, EGCG, GCG 및 $\mathrm{ECG}$ 의 함량이 유의차 있게 감소되었고 $(p<0.05), \mathrm{GC}$ 및 caffeine함량은 감소되었지만 유의차가 없었다. Roasting에 의한 이와 같은 catechin 감소는 total phenol 함량(Table 3)에는 큰 영향을 미치지 않았다.

\section{CLGT의 휘발성분 함량}

GTL과 CLGT시료에 함유된 휘발성 성분을 분석하였다 (Table 5, 6). GTL에서 39개 화합물이 검출되었고 그 중 2-methyl butanal, acetic acid, 4-tert-butyl cyclohexanol, cis-ocimene, 1-ethyl pyrrole, limonene, 2-methyl propanal, propanoic acid, tererpineol, cis-geraniol의 함량(면적비가 $1.0 \%$ 이상인 화합물)이 상대적으로 높았다. 반면에 CLGT에는 33 개 화합물이 검출되었고, 그 중 2-methyl butanal, 1-ethylpyrrole, acetic acid, o-xylene, 4-tert-butyl cyclohexanol, limonene, cis-ocimene, cis-2,6-dimethyl-2,6-octadiene, 1-ethyl- 

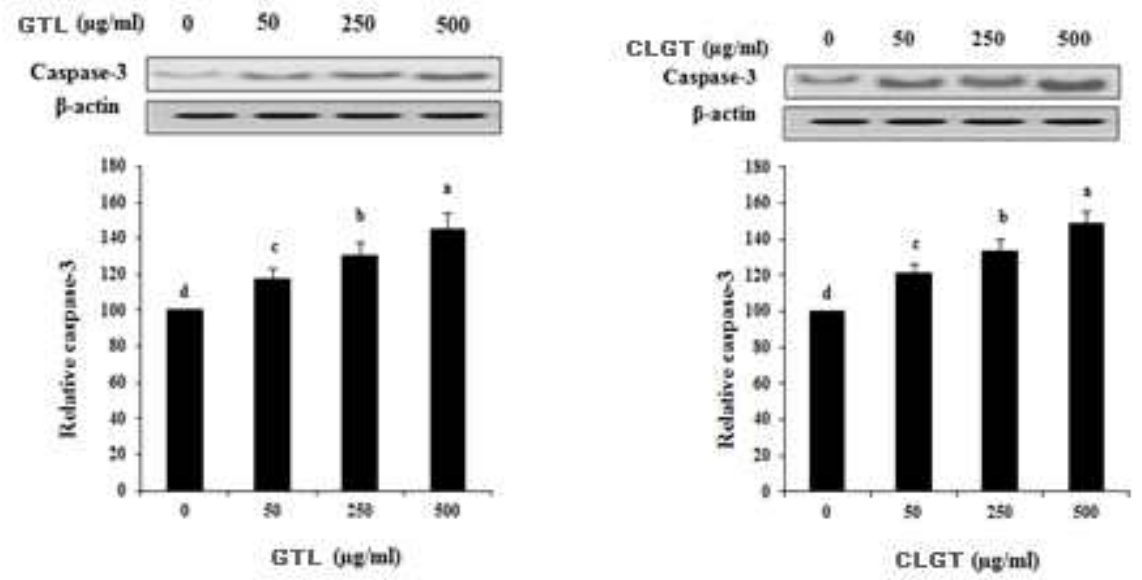

Fig. 3. Effects of GTL and CLGT preparation on caspase-3 protein expression on human breast cancer MCF-7 cells grown for 2 days. Total cellular extract (40 $\mathrm{ug}$ protein/lane) was analyzed for caspase-3.
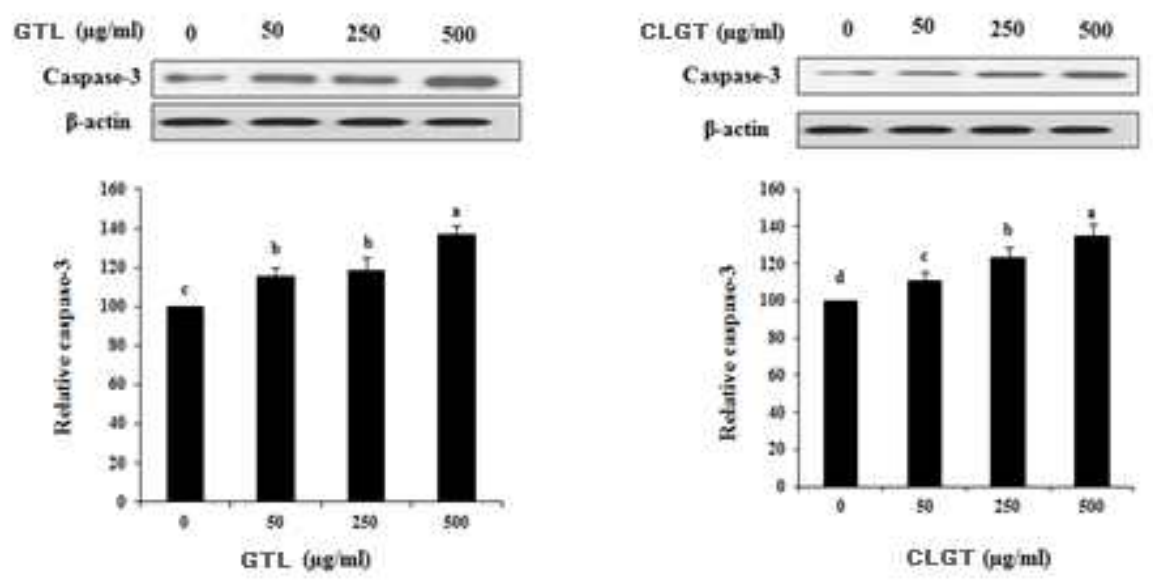

Fig. 4. Effects of GTL and CLGT preparation on caspase-3 protein expression on PC-3 cells grown for 2 days. Total cellular extracts (40 $\mu \mathrm{g}$ protein/lane) were analyzed for caspase-3.

Table 3. Antioxidant activity, and amounts of total phenolic compound, total protein and total sugar in GTL and CLGT preparation

\begin{tabular}{ccccc}
\hline Sample & Antioxidant activity $\left[\mathrm{SC}_{50}\right]^{1)}$ & Total phenol $(\mathrm{GA} \text { meq/g) })^{2)}$ & Total protein $(\%)$ & Total sugar $(\%)$ \\
\hline GTL & $14.1 \pm 1.5^{\mathrm{a} 3)}$ & $90.85 \pm 9.58^{\mathrm{a}}$ & $4.3 \pm 0.3^{\mathrm{a}}$ & $6.5 \pm 2.0^{\mathrm{a}}$ \\
CLGT preparation & $11.6 \pm 1.1^{\mathrm{a}}$ & $86.21 \pm 7.67^{\mathrm{a}}$ & $2.8 \pm 0.1^{\mathrm{b}}$ & $5.6 \pm 1.0^{\mathrm{a}}$ \\
\hline
\end{tabular}

${ }^{1)}$ Antioxidant activity is presented as a vitamin $\mathrm{C} \mathrm{meg} / \mathrm{g}$ and then $\mathrm{SC}_{50}$, which is a sample concentration to be reduced a $50 \%$ DPPH color after one min reaction.

${ }^{2)}$ Gallic acid mg equivalent per g sample.

${ }^{3)}$ Data are presented as mean \pm standard deviation $(n=3)$. Means with different superscript small letters in column represent a significant difference at $p<0.05$ by t-test.

1H-pyrrole-2-carboxaldehyde, terpinolen, 2,6-dimethyl- 1,5heptadiene, trans-ocimene의 함량(면적비가 $1.0 \%$ 이상인 화 합물)이 높았다.

Roasting에 의해 증가되었거나 생성된 화합물도 있었고, 감 소되었거나 없어진 화합물도 있었다. GTL에서 검출된 39개 화합물 중 2-methyl propanal 및 2,5,5-trimethyl-1-hexen3 -yne을 비롯하여 17 개 화합물이 파괴되어 없어졌고, 2-men- tyl butanal을 포함하여 10개 화합물이 감소되었다(Table 6). 또한 CLGT에 검출된 33 화합물 중 o-xylene, 1-ethyl-1Hpyrrole-2-carboxaldehyde, 1-methyl-2-formpyrrole을 포함하 여 11개 화합물이 생성되었고, 1-ethyl pyrrole, 2,6-dimethyl1,5-heptadiene, phenylethyl hexanoic acid 및 1-octan-3-ol을 비롯한 12 개 화합물의 함량은 증가되었다(Table 5). 이와 같은 결과는 Kenji와 Hisami가 pan-fried한 Japanese Kumara-cha 
Table 4. Amount of phenolic compounds in GTL and CLGT preparation

\begin{tabular}{lcc}
\hline Compound $^{1)}$ & \multicolumn{2}{c}{ Amount $(\mathrm{mg} / \mathrm{kg}$ sample) } \\
\cline { 2 - 3 } Gallocatechin (GC) & $3008.8 \pm 494.0^{\mathrm{a} 1)}$ & CLGT preparation \\
Epigallocatechin (EGC) & $1052.2 \pm 323.8^{\mathrm{a}}$ & $2131.1 \pm 434.8^{\mathrm{a}}$ \\
Catechin & $135.4 \pm 145.8^{\mathrm{a}}$ & $205.8 \pm 117.7^{\mathrm{b}}$ \\
Caffeine & $2451.0 \pm 239.6^{\mathrm{a}}$ & $648.3 \pm 33.7^{\mathrm{b}}$ \\
Epicatechin (EC) & $1181.1 \pm 131.9^{\mathrm{a}}$ & $2446.9 \pm 198.8^{\mathrm{a}}$ \\
Epigallocatechin gallate (EGCG) & $8179.5 \pm 208.8^{\mathrm{a}}$ & $429.6 \pm 30.7^{\mathrm{b}}$ \\
Gallocatechin gallate (GCG) & $4017.9 \pm 442.0^{\mathrm{a}}$ & $3976.2 \pm 140.7^{\mathrm{b}}$ \\
Epicatechin gallate (ECG) & $1143.3 \pm 160.5^{\mathrm{a}}$ & $2774.2 \pm 87.7^{\mathrm{b}}$ \\
\hline
\end{tabular}

${ }^{1)}$ Compounds were identified and derived from Fig. 5 chromatograms of GTL and CLGT preparation.

${ }^{2)}$ Data are presented as mean \pm standard deviation $(n=3)$. Means with different small superscript letters in a row represent significant difference at $p<0.05$ by t-test.

Table 5. Major flavor compounds increased and newly-formed in CLGT preparation by roasting GTL ${ }^{1)}$

\begin{tabular}{|c|c|c|c|}
\hline \multirow{2}{*}{ Compound $^{2)}$} & \multirow{2}{*}{$\mathrm{RT}^{3)}$} & \multicolumn{2}{|c|}{ Composition (\%) } \\
\hline & & GTL & CLGT preparation \\
\hline Pyrrole,1-ethyl & 6.62 & 2.1 & 7.9 \\
\hline o-Xylene & 8.43 & - & 5.1 \\
\hline 1,5-Heptadiene,2,6-dimethyl & 8.85 & 0.5 & 1.2 \\
\hline Hexanoic acid, phenethyl ester & 9.08 & 0.5 & 0.8 \\
\hline 1-Methyl-2-formpyrrole & 10.08 & - & 0.3 \\
\hline 1-Octen-3-ol & 12.05 & 0.3 & 0.8 \\
\hline 4-Tert-butylcyclohexanol & 12.32 & 4.4 & 4.6 \\
\hline cis-2,6-Dimethyl-2,6-octadiene & 12.61 & 0.5 & 2.6 \\
\hline 1R-a-Pinene & 12.81 & - & 0.5 \\
\hline a-Terpinen & 13.22 & - & 0.6 \\
\hline$\beta$-Cymene & 13.47 & - & 0.3 \\
\hline Limonene & 13.62 & 1.3 & 3.5 \\
\hline trans-Ocimene & 13.83 & 0.7 & 1.1 \\
\hline cis-Ocimene & 14.17 & 2.5 & 2.9 \\
\hline 1H-Pyrrole-2-carboxaldehyde,1-ethyl & 14.22 & - & 2.1 \\
\hline$\delta$-Terpinen & 14.55 & - & 0.3 \\
\hline cis-Linalool oxide & 14.97 & 0.44 & 0.69 \\
\hline Terpinolen & 15.41 & 0.7 & 1.4 \\
\hline Benzenamide,2-methoxl-4-methyl & 16.22 & & 0.7 \\
\hline Pyrazine,3,5-diethyl-2-methyl & 17.51 & - & 0.3 \\
\hline Methyl salicylate & 18.68 & - & 0.5 \\
\hline Napthalene,1,2-dihydro-1,5,8-trimetyl & 23.22 & 0.2 & 0.7 \\
\hline Palmitic acid, methyl ester & 36.23 & - & 0.2 \\
\hline 23 & Total $(\%)$ & 75.24 & 61.66 \\
\hline
\end{tabular}

${ }^{1)}$ GTL was roasted in a temperature-controlled frying-pan at $240^{\circ} \mathrm{C}$ for $60 \mathrm{~min}$.

${ }^{2)}$ Compounds were identified by GC-MS.

${ }^{3)}$ Retention time ( $\mathrm{min}$ ) of compounds appeared on GC chromatograms given samples analyzed by a DB-8 capillary column.

와 Chinese Longing tea에서 각각 51 및 52 개의 화합물을 검출 한 결과와 유사하였다[11].

\section{고 찰}

녹차는 많은 비 휘발성 및 휘발성 화합물을 함유하고 있어
이들 화합물 조성이 복합적으로 녹차의 향미에 영향을 미친다 $[13,17,23]$. GLT를 녹차로 제조하기 위한 덖음 열처리는 비 휘발성 화합물인 caffeine, catechin, EC, EGC, ECG, EGCG 등을 분해시키거나 증발 유실시켰고[13], 휘발성 화합물인 pentanol, cis-3-hexenol, linalool oxide I, linalool oxide II, $\beta$ ionone은 감소시켰고, phenylacetaldehyde, linalool, linalool 

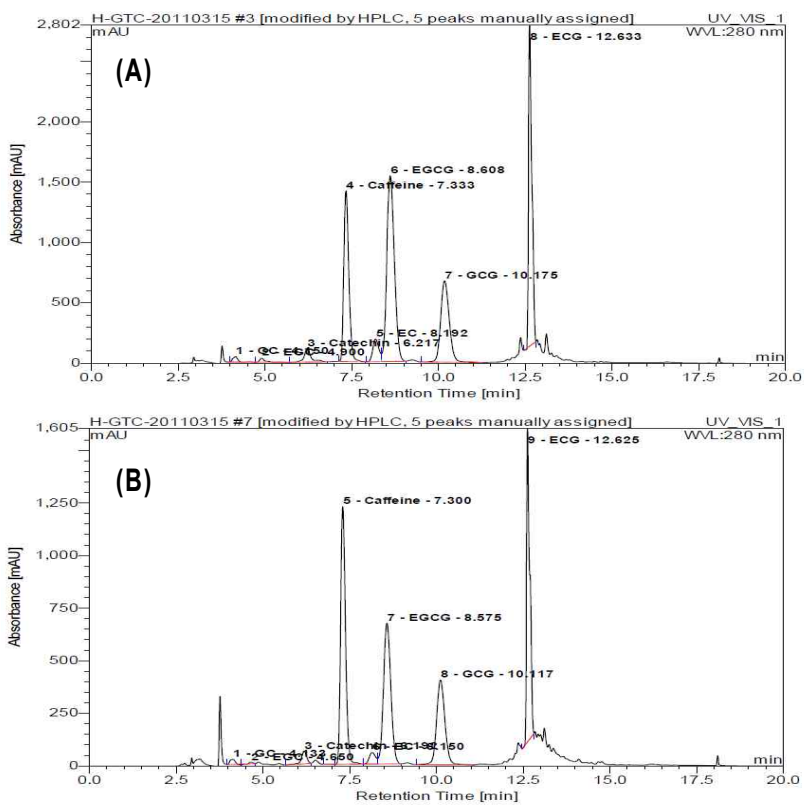

Fig. 5. HPLC chromatograms of phenolic compounds in GTL (A) and CLGT preparation (B). oxide III, a-terpineol, indole은 증가시켰다 $[13,17]$. 따라서 덖 음 열처리는 GTL에 함유된 향미성분의 조성을 변화시켜, 녹 차에 고유 향미를 부여하기 때문에, 덖음 열처리보다 더 강한 열처리(roasting)는 GTL을 커피와 유사한 향미가 부여된 CLGT를 제조할 수 있음을 의미한다.

커피향미에 관여하는 성분도 아주 복잡하다. 일반적으로 coffee bean을 roasting하면 휘발성 물질인 methanethiol, acetic acid, 3-methyl-butanoic acid, 2-furfuryl methyl disulfide, 4-hydroxy-2,5-dimethyl-3(2H)-furanone 등은 증가하고 2-furfurylthiol, methional, 3-mercapto-3-methyl butyl formate 등 은 감소하였다[15]. 비 휘발성 물질인 arginine, cysteine, lysine, serine과 같은 유리 아미노산은 파괴되고 탄수화물, sucrose, arabinogalactan 등도 파괴되어 coffee의 맛과 향에 관여 하는 것으로 보고되어 있다 $[18,28]$. 또한 커피의 향미는 커피 에 존재하는 향미성분의 복잡한 조합에 의해 부여되며, roasting 정도(시간, 온도)에 따라 상이한 향미를 나타내기 때문에, 이와 같은 커피 향미변화는 GTL을 커피생산 조건과 유사하게 roasting함으로써 CLGT를 생산할 수 있을 것임을 시사한다.

Table 6. Major flavor compounds decreased and disappeared in CLGT preparation by roasting GTL ${ }^{1)}$

\begin{tabular}{|c|c|c|c|}
\hline \multirow{2}{*}{ Compound $^{2)}$} & \multirow{2}{*}{$\mathrm{RT}^{3)}$} & \multicolumn{2}{|c|}{ 1-ethyl } \\
\hline & & GTL & CLGT preparation \\
\hline Propanal,2-methyl & 2.75 & 1.7 & - \\
\hline Butanal,2-methyl & 3.48 & 23.8 & 10.0 \\
\hline Acetic acid & 4.77 & 10.0 & 7.8 \\
\hline Propanoic acid & 5.42 & 2.1 & - \\
\hline 1-Hexen-3-yne,2,5,5-trimethyl & 7.61 & 0.5 & - \\
\hline Heptanal & 9.47 & 0.4 & - \\
\hline Benzaldehyde & 11.44 & 0.4 & 0.3 \\
\hline Hexanoic acid, vinyl ester & 12.20 & 0.6 & - \\
\hline Octane,2,3,6,7-tetramethyl & 13.71 & 0.7 & 0.4 \\
\hline Octane,3,6,-dimethyl & 14.32 & 0.7 & 0.3 \\
\hline Decane, $2,6,7$,triethyl & 14.39 & 0.2 & - \\
\hline Linalool oxide & 14.69 & 0.38 & - \\
\hline cis-Linalool oxide & 14.97 & 0.44 & 0.69 \\
\hline decan,2,3,6-trimethyl & 15.03 & 0.24 & - \\
\hline 1,5,7-Octatrien-3-ol,3,7-dimethyl & 15.97 & 0.7 & 0.2 \\
\hline Nonanal & 16.01 & 0.2 & - \\
\hline Perilen & 16.25 & 0.3 & - \\
\hline Epoxylinaol & 18.10 & 0.3 & - \\
\hline Tererpineol & 18.78 & 1.4 & - \\
\hline a-Terpieol & 18.87 & 0.4 & 0.3 \\
\hline (-)- $\beta$-Pinene & 19.59 & 0.3 & - \\
\hline cis-Geraniol & 20.32 & 1.3 & 0.4 \\
\hline 2,3-Dimethyl decane & 20.98 & 0.2 & - \\
\hline Cadinene & 27.34 & 0.4 & - \\
\hline a-Farnesene & 28.37 & 0.3 & - \\
\hline Caffeine & 34.93 & 0.7 & - \\
\hline Phytol & 39.71 & 0.6 & 0.5 \\
\hline
\end{tabular}

${ }^{1)} \mathrm{GTL}$ was roasted in a temperature-controlled frying-pan at $240^{\circ} \mathrm{C}$ for $60 \mathrm{~min}$.

${ }^{2)}$ Compounds were identified by GC-MS.

${ }^{3)}$ Retention time ( $\mathrm{min}$ ) of compounds appeared on GC chromatograms given samples analyzed by a DB-8 capillary column. 
녹차에 커피를 blending하여 커피녹차 혼합물을 제조하였 으나, 이는 녹차의 향미와 커피의 향미가 혼재하고, 녹차의 강한 풋내를 부여하기 때문에 커피와 유사한 향미를 부여하지 못했다[14]. 그러나 본 연구에서는 GTL을 덖음 처리 이상의 조건인 $240^{\circ} \mathrm{C}$ 에서 1 시간 roasting하여 CLGT를 제조하였다 (Table 1, 2). 이 roasting 조건은 GTL의 total phenol 함량에는 영향을 미치지 않았고, total sugar 함량과 total protein 함량을 감소 $(p<0.05)$ 시켰고(Table 3), EGCG, GCG, GC 및 caffeic acid를 포함하여 8개 비 휘발성 중 GC와 caffeine를 제회한 나머지 6 화합물은 유의성 $(p<0.05)$ 있게 감소시켰다(Table 4). 또한 CLGT에는 33개의 휘발성 성분이 검출되었는데(Table 5, 6), 이들은 GTL에 비하여 2-mentyl butanal을 포함하여 10개 화합물은 감소되었고(Table 5), 1-ethyl-1H-pyrrole-2-carboxaldehyde을 포함하여 11개가 생성되었고, 2,6-dimethyl-1,5hepta-diene을 포함하여 12 화합물은 증가되었다(Table 6). 따 라서 CLGT는 roasting에 의해 생성된 화합물, 함량이 증가된 화합물 및 함량이 감소된 화합물의 상호 복합작용에 의해 커 피에 가까운 향미를 나타내는 것으로 추정된다.

CLGT는 roasted coffee bean과 같이 brown색을 띄었으나 burning smell은 많이 나지 않았다. 그러나 강한 조건하에서 roasting한 GTL (예, $240^{\circ} \mathrm{C}, 2$ 시간)은 갈색이었고 burning smell이 났다. 연녹색의 GTL이 roasting에 의해 갈색을 띄는 것은 녹차에 함유된 단백질, 다당류, chlorogenic acid, trigonellin 등이 분해되어 고분자 중합물로 전환되어 갈색을 띄게 된다[4]. 특히 당과 아미노산 반응에 의한 Millard reaction, melanoidin 생성 반응, polyphenol 화합물의 중합에 의한 browning reaction이 녹차나 커피의 갈색에 중요한 영향을 미 친다[5]. 본 연구에서도 CLGT과 GTL을 비교하였을 때, total phenol 함량은 감소되지 않았지만, total 당과 total protein 함량이 유의성 있게 감소되어, 당과 protein성분이 roasting 과정 중 browning reaction에 관여하여 CLGT에 갈색을 나타 낸 것으로 생각된다.

Roasting은 식품을 고온으로 가열하여 고유한 향미와 색깔 을 얻기 위한 방법으로 널리 사용되고 있다[5,19]. 이 roasting 은 식품에 함유된 성분들을 분해 및 축합 등의 반응을 통해 유용성분을 생성함으로써 그 식품에 고유한 향미나 색깔을 부여함은 물론 항산화작용 및 항균작용 등의 기능성을 부여한 다 $[19,27]$. 그러나 roasting의 정도에 따라 차이는 있겠지만, 일반적으로 고온가열처리는 돌연변이성을 증가시키는 경향 이 있다 $[9,12,20]$. 따라서 본 연구에서도 고온으로 가열처리 $\left(240^{\circ} \mathrm{C}, 1 \mathrm{hr}\right.$ )한 GTL (즉 CLGT)의 물 추출물의 인체 암세포 (MCF-7, PC-3), 인체 정상세포(SK-N-SH)와 동물정상세포 (H9c2)에 대한 CLGT의 세포독성을 검증하였다(Fig. 1, 2). 그 결과 CLGT는 농도 의존적으로 MCF-7과 PC-3에 대해 강한 세포독성을 나타내었으나 GTL과의 효과 차이는 없었고(Fig. 1), 또한 SK-N-SH세포와 H9c2세포에 대해서는 GTL과 마찬가
지로 전혀 세포독성이 없었다(Fig. 2). 이와 같은 CLGT의 인체 암세포에 대한 세포독성은 Pan 등의 연구 결과[20]와 같이 mitochondria의 dysfunction에 의한 apoptosis에 기인하는 것으 로 추정되었다(Fig. 3, 4). CLGT를 생산한 roasting 조건( $240^{\circ} \mathrm{C}$, 1시간)에서는 인체 암세포나 정상세포 및 쥐 심근세포에 독성 을 나타내는 물질도 생성되었을 수도 있고, 항독성물질도 생 성되어 이들이 복합적으로 GTL의 독성과 유사한 결과를 유도 한 것으로 생각된다.

본 연구에서는 CLGT의 물 추출물을 GTL 물 추출물과 비교 하여 인체암세포 주인 MCF-7와 PC-3 및 인체정상세포 주인 SK-N-SH와 쥐심근 정상세포 주인 H9c2에 대하여 세포독성을 검증하였다. 이들 물 추출물 모두 $500 \mathrm{ug} / \mathrm{ml}$ 의 고농도에서 암세포인 MCF-7 세포에 대하서는 88\% (Fig. 1A), PC-3세포에 대해서는 $70 \%$ 의 세포독성이 나타났고(Fig. $1 \mathrm{~B})$, 정상세포인 SK-N-SH 및 H9c2에 대해서는 5\%의 세포독성을 나타내었다 (Fig. 2). 이와 같은 결과(암세포에는 독성이 강하고, 정상세포 에 대해서는 독성이 약한 결과)를 정확히 비교할 수 있는 결과 는 없지만, Babich 등[3]이 ECG가 충치에서 분리한 암세포와 정상세포에 대한 세포독성이 상이하다는 보고, 즉 $\mathrm{ECG}$ 의 세 포독성은 정상세포에서는 아주 낮고, 암세포에 대해서는 아주 강하다는 보고와 유하였다.

결론적으로, GTL을 roasting $\left(240^{\circ} \mathrm{C}, 1\right.$ 시간 $)$ 하여 CLGT를 조제하였고, 이 CLGT는 GTL과 비교하여, 인체 암세포나 정상 세포 및 쥐 심근세포에 대해 독성 차이는 없었다. 따라서, 이 CLGT는 커피 대용으로 사용할 수 있을 것이다.

\section{감사의 글}

이 연구는 경상대학교 BK21 program 지원사업과 하동녹차 연구소 RIS 지원사업에 의해 수행되었습니다.

\section{References}

1. Agarwal, R., Katiyar, S. K., Zaidi, S. I. A. and Mukhtar, H. 1992. Inhibition of skin tumor promoter-caused induction of epidermal ornithine decarboxylase in SENCAR mice by polyphenolic fraction isolated from green tea and its individual epicatechin derivatives. Cancer Res 52, 3582-3588.

2. Aronson, D. 2004. Pharmacological prevention of cardiovascular aging-targeting the Maillard reaction. $\mathrm{Br} J$ Pharmacol 142, 1055-1058.

3. Babich, H., Krupka, M. E., Nissim, H. A. and Zuckerbraun, H. L. 2005. Differential in vitro cytotoxicity of (-)-epicatechin gallate (ECG) to cancer and normal cells from the human oral cavity. Toxicology in Vitro 19, 231-242.

4. Brand-Williams, W., Cuvelier, M. E. and Berset, C. 1995. Use of a free radical method to evaluate antioxidant activity. Technology 28, 25-30.

5. Choi, S. H. 2010. Effects of pyrazines, reaction products of 
Maillard reaction on flavor of green tea and substitution tea. J Korean Tea Soc. 16, 1-7.

6. Conney, A. H., Wang, Z. Y., Huang, M. T., Ho, C. T. and Yang, C. S. 1991. Inhibitory effect of green tea on tumorigenesis by chemicals and ultraviolet light. Prev Med 21, 361-369.

7. Dubois, M., Gilles, K. A., Hamilton, J. K., Rebers, P. A. and Smith, F. 1956, Calorimetric method for determination of sugars and related substances. Analyt Chim 28, 350-356.

8. El-Shahawi, M. S., Hamza, A., Bahaffi, S. O., Al-Sibaai, A. A. and Abduljabbar, T. N. 2012. Analysis of some selected catechins and caffeine in green tea by high performance liquid chromatography. Food Chem 134, 2268-2275.

9. Houessou, J. K., Maloug, S., Leveque, A. S., Delteil, C., Heyd, B. and Camel, V. 2007. Effect of roasting conditions on the polycyclic aromatic hydrocarbon content in ground arabica coffee and coffee brew. J Agric Food Chem 55, 9719-9726.

10. Kaur, S., Greaves, P., Cooke, D. N., Edwards, R., Steward, W. P., Gescher, A. J. and Marczylo, T. H. 2007. Breast cancer prevention by green tea catechins and black tea theaflavins in the C3(1) SV40. $t, t$ antigen transgenic mouse model is accompanied by increased apoptosis and a decrease in oxidative DNA adducts. J Agric Food Chem 55, 3378-3385.

11. Kenji, K. and Hideki, M. 2002. Identification of potent odorants in different green tea varieties using flavor dilution technique. J Agric Food Chem 50, 5660-5663.

12. Kikugawa, K., Kato, T. and Takahashi, S. 1989. Possible presence of 2-amino-3,4-dimethyl imidazo[4,5-f]quinoline and other heterocyclic amine-like mutagens in roasted coffee beans. J Agric Food Chem 37, 881-886.

13. Kim, E. S., Liang, Y. R., Jin, J., Sun, Q. F., Lu, J. L., Du, Y. Y. and Lin, C. 2006. Impact of heating on chemical compositions of green tea liquor. Food Chem 103, 1263-1267.

14. Kim, Y. K., Kim, H. N., Choi, J. Y. and Baig, J. H. 2007. Coffee-flavored mixed tea with excellent taste and preparing method thereof. Patent pending, 10-2007-0102701, Korea.

15. Kumazawa, K. and Masuda, H. 2003. Investigation of the change in the flavor of a coffee drink during heat processing. J Agric Food Chem 51, 3274-3278.

16. Lee, G. D., Jeong, Y. J., Park, N. Y. and Kwon, J. H. 1999. Monitoring for the color formation of a Doraji tea by soaking of threonine and sucrose solution and roasting. Korean J Food Sci Technol 31, 938-944.

17. Lee, S. I., Jeon, D. B., Kim, J. S., Jung, I. S., Hong, Y. S., Seo, H. Y., Park, K. H. and Kim, K. S. 2011. Analysis of volatile flavor components in fresh leaves and roasted green tea. J Korean Tea Soc 17, 46-53.

18. Lyman, D. J., Benck, R., Dell, S., Merle, S. and Jacqueline, M. W. 2003. FTIR-ATR analysis of brewed coffee: effect of roasting conditions. J Agric Food Chem 51, 3268-3272.
19. Miller, A. G., Meade, S. J. and Gerrard, J. A. 2003. New insights into protein cross linking via the Maillard reaction: structural requirement, the effect on enzyme function, and predicted efficacy of cross linking inhibitors as anti-aging therapeutics. Bioorg Med Chem 11, 843-852.

20. Nishigaki, R., Watanabe, T., Kajimoto, T., Tada, A., Takamura-Enya, T., Enomoto, S., Nukaya, H., Terao, Y., Muroyama, A., Ozeki, M., Node, M., Hasei, T., Totsuka, Y. and Wakabayashi, K. 2009. Isolation and identification of a novel aromatic amine mutagen produced by the Maillard reaction. Chem Res Toxicol 22, 1588-1593.

21. Pan, M. H., Kang, H. J., Chen, W. J., Lo, C. Y., Li, S., Sang, S. and Ho, C. T. 2008. Induction of apoptosis by acetylated black tea polyphenol through reactive oxygen species production, cytochrome $\mathrm{c}$ release, and caspases activation in human leukemia HL-60 cells, pp. 345-361, In Shibamoto, T., Kanazawa, K., Shahidi, F. and Ho, C. T. (eds.), Functional Food and Health, Vol. 993, American Chemistry Society.

22. Rakib, M. A., Kim, Y. S., Jang, W. J., Jang, J. S., Kang, S. J. and Ha, Y. L. 2011. Preventive effect of $t$,t-conjugated linoleic acid on 12-Otetradecanoyl- phorbol-13-acetate-induced inhibition of gap junctional intercellular communication in human mammary epithelial MCF-10A Cells. J Agric Food Chem 59, 4164-4170.

23. Park, J. H., Nam, S. H., Choi, J. J. and Hwang, H. S. 2010. Comparison of component content between envirnomental-frendly and conventional green tea. J Korean Tea Soc 16, 106-110.

24. Park, N. Y., Jeong Y. J. and Kwon, J. H. 2007. Changes in flavor compounds of Polygonatum odoratum root during roasting. Korean J Food Sci Technol 39, 99-103.

25. Sakagami, H., Asano, K., Hara, Y. and Shimamura, T. 1992. Stimulation of human monocyte and polymorphonuclear cell iodination and interleukin-1 production by epigallocatechin gallate. J Leukoc Biol 51, 478-83.

26. Singleton, V. L. and Rossi, J. A, Jr. 1965. Colorimetry of total phenolics with phosphomolybdic-phosphotungstic acid reagents. Am J Enol Viticult 16, 144-158.

27. Summa, C., McCourt, J., Cammerer, B, Fiala, A., Probst, M., Kun, S., Anklam, E. and Wagner, K. H. 2008. Radical scavenging activity, anti-bacterial and mutagenic effects of cocoa bean Maillard reaction products with degree of roasting. Mol Nutr Food Res 52, 342-351.

28. Wei, F., Furihata, K., Koda, M., Hu, F., Miyakawa, T. and Tanokura, M. 2012. Roasting process of coffee beans as studied by nuclear magnetic resonance: time course of changes in composition. J Agric Food Chem 60, 1005-1012.

29. You, J. O. 2010. A study on usage pattern of green tea and analysis for its expansion factor. Korean J Food Sci Technol 44, 931-934. 
초록 : Coffee-like green tea의 인체암세포 및 정상세포에 대한 독성

문연규 $^{1} \cdot$ 권애경 ${ }^{1} \cdot$ 김종철 ${ }^{2} \cdot$ 박한민 $^{3} \cdot$ 조용운 ${ }^{4} \cdot$ 정관주 ${ }^{5} \cdot$ 하영래 ${ }^{1} \star$

( ${ }^{1}$ 경상대학교 대학원 응용생명과학부, ${ }^{2}$ (재)하동녹차연구소, ${ }^{3}$ 경상 대학교 환경재료과학과, ${ }^{4}$ 경남과학기술대 학 제약공학과, ${ }^{5}$ (재)바이오21센터)

커피와 유사한 향미기를 갖는 녹차(Coffee-like green tea: CLGT)를 제조하고 이의 인체 유방암세포 주 MCF-7, 인체 전립선암세포 주 PC-3, 인체 신경모세포 주 SK-N-SH 및 쥐 심근세포 주 H9c2에 대한 세포독성을 연구하였 다. 녹차엽(GTL)을 $240^{\circ} \mathrm{C}$ 에서 1 시간 roasting한 녹차가 커피와 가장 유사한 향미를 나타내었다. CLGT는 GTL과 비교하여 인체 암세포 및 정상세포와 쥐 심근세포에 대한 세포독성 차이가 없었다. GTL의 roasting은 ECG 등의 catechin 성분과 total protein은 유의성 있게 감소시켰지만, total phenol 및 total sugar는 유의성 있는 감소시키 지 않아, 이와 같은 화합물 조성의 변화가 GTL에 커피유사 향미를 제공하였을 것이다. 따라서 이들 결과는 CLGT 이 인체에 안전하여 커피 대용품으로 사용할 수 있음을 의미한다. 